All in all, this is an impressive and comprehensive collection of papers which document very thoroughly the recent progress in this brave new field. The enterprise of Edinburgh University in fostering many of the developments reported has been amply rewarded, and Professor Michie is to be congratulated on the success of his vigorous initiative in building up his own group and also organizing these very successful conferences.

StANLey GiLl

\section{MACHINE PROGRAMMING}

\section{Basic Machine Principles}

By J. K. Iliffe. (Macdonald Computer Monographs.) Pp. 86. (Macdonald: London, 1968.) $25 s$.

THIs book, like others in the series which I have examined, has been prepared with great care and introduces a great many technical details of machine code programming in a lucid manner. There is no doubt that the book will be useful to that class of person defined by the author: ". . . of primary interest to logic designers and programmers who occupy themselves with the boundary between the 'hard' and 'soft' parts of a computer'. Because of this I would suggest that the title chosen for the book implies a far greater "hard" bias than the book has.

My difficulty in giving unconditional praise for this book lies not in the presentation of its material but in the principle adopted. Though there are advantages of introducing a hypothetical language for a hypothetical machine, these are outweighed, in my view, by the practical disadvantages to most readers of having to learn a system which they can never use. I think one learns far more from the experiences (often bitter) of putting programs through a computer than from a great deal of theoretical study. For this reason, study of the symbolic machine code of a common computer series is more practicable. But here is the author's dilemma. He is clearly dissatisfied with conventional computers and has proposed in his basic machine one which attempts to overcome some of their limitations. This will appeal to logic designers and software design programmers. For them the proposals and the very explicit sections on, for example, executive functions and virtual stores and paging are most valuable. The world will benefit if manufacturers make use of some of these ideas in the design of future machines, but by adopting this approach the author has produced a specialist book for a minority class of reader. This he has done extremely well.

\section{R. J. ORD-Smith}

regions, usually based on collections of particular expeditions, and taxonomic monographs. His most important monographs were that on Microhylidae (1934) and his revision of the Australasian frogs of the family Leptodactylidae (1940). The amount of detailed and critical work that goes into this type of monograph is little understood by the general zoologist. The formal descriptions of species, the "synonymies" and the nomenclature itself contain highly concentrated factual and theoretical information. It is at the same time a work of reference and a working hypothesis, and Parker's monographs were of high quality.

Parker's work was interrupted by the Second World War, during which he was seconded to an administrative post in the Admiralty. On his return to the Museum, in spite of new responsibilities as head of the Department of Zoology, he found time for further systematic work, which was enlivened by interpretative discussions. He felt a little sore that his own university did not recognize systematic work as qualifying for its doctorate, and it may have been for this reason that he submitted a thesis to the University of Leyden, where taxonomy was appreciated. For a taxonomic and zoogeographical study of "The Snakes of Somaliland and the Sokotra Islands" (1949) and a lively "disputation" on the species concept he was awarded a doctorate by that university. His philosophical position was further exemplified by his contribution to a symposium on "The Species Concept in Palaeontology", published by the Systematics Association.

Parker made an excursion into ichthyology when in 1947 he went with Dr Harrison Matthews to the Isle of Soay in the Hebrides to study the great carcasses of the basking shark brought in by a fishery that Gavin Maxwell temporarily conducted there. Later he collaborated with Dr Boeseman to throw light on the probable inactivity of this shark in our waters during winter, when it sheds its long gill-rakers and so deprives itself of the means of filtering plankton, which at any rate is deficient in these latitudes in winter. After his retirement he helped Dr F. C. Stott to investigate and interpret basking shark material caught off the coast of Ireland. These studies have provided the greater part of our knowledge of the life history of Cetorhinus maximus.

Although he did no such original bionomic research for the group he was particularly interested in, Parker published in 1963 a much appreciated book on snakes treated as living animals related to their natural environments. Here his logical thinking and lucid style were deployed successfully in popular exposition.

\section{Correspondence}

\section{Is Botany Dead?}

SIR,- - In 1964 at the tenth International Botanical Congress I made the point, that clearly needs reiteration, that botany is so far from dead that we now take almost for granted the services of plant physiologists to the study of crop growth; of mycologists and plant pathologists to the constant protection against fungi and bacteria of food growing in the field or kept in storage, and that we have accepted or almost forgotten that the origin of the vast new industry of weed control by selective herbicides was in the botanical study of the natural growth substances of plants. If the role of botany in the great areas of plant technology remains in doubt, let us recall how the leading research posts are commonly held by scientists who were trained as botanists, for example, the professors of agriculture in Oxford and Cambridge, and the heads of Rothamsted Research Station, the National Institute of Agricultural Botany and the Scottish Institute of Plant 